\title{
English language teachers' perspectives on learner autonomy
}

\author{
Chetnath Panta \\ Kathmandu University, Nepal
}

\begin{abstract}
This study explores the perceptions and practices of the English language teachers to create autonomous learning environment in the context of Nepalese secondary EFL classroom. The study further unpacks the role of the teachers in creating better learning opportunities for learners so as to promote learner autonomy. The research is based on interpretive paradigm to look into kaleidoscopic view of variety of perspectives, classroom practices and emerging dilemmas of the teachers. Based on the findings, the research showcases the deep rooted social practices and myth to bring tensions in the relation between teachers and students. The school environment has to be homely and autonomy supportive. It seems pertinent to think over the concept of learner autonomy globally and act locally adapting the global trends and issues of teaching and learning, and at the same time, there is a dire need to remain mindful of the translated concept of learner autonomy thinking contextually and pragmatically.
\end{abstract}

Key Words: Learner autonomy, kaleidoscopic view, interpretivism, ethnography, paradigm

\section{Introduction}

The notion of learner autonomy caught my attention as I explored disparity between what child right activists and educationists advocate - "a liberal society should value and protect individual freedom" (Benson, 2008) and what actually happens in the classroom. In this regard, Bakhtin (1981) highlights that all relations are dynamic and are in developing process. Nothing is static in relationship between self and others. It keeps changing.

Similarly, I also advocate for the negotiated and dynamic relationship between teacher and student. I am more critical of the teachers who opted for punishment and deadly habits such as criticizing, underestimating and blaming the learners and try to justify that they are doing so in order to develop better habits and positive thinking of the learners 


\section{Statement of the problem}

My growth as a student was quite painful as I was often not allowed by the teachers to express my views. Most of the time, I was asked to keep quiet and listen to the explanation of the teachers. I rarely got a chance to unleash my potential. I think this is not the issue only with me, but may be with many across the country. So, with this issue in mind, I got interested in carrying out a research to explore the perceptions and practices of the EFL teachers to foster learner autonomy.

Subscribing to the notion of autonomy as self-governing, I understood that learning arises from interaction and interaction is characterized by interdependence (Little, 1999). Generally, the students tend to hesitate to express their feelings. That is the reason why students hardly remain engaged in learning from interaction between teachers and students. I made an attempt to see if learners really had autonomy in the classroom. Many teachers were found opting for authoritarian practices and carrying out the legacy imprinted in their mind. It is claimed that such practices cripple the ability of the learners. It is unwise to demean the role of learners in the process of learning.

In my experience as a student as well as a teacher, I have realized that there are problems of putting ideas of learner autonomy into practice. But willingness of teachers is a key factor to promote learner autonomy. I explored understanding of teachers on learner autonomy and their practices in order to promote learner autonomy in the classroom. Being, surviving, sustaining and creating identity is a professional challenge for teachers.

Our secondary level curriculum expects our learners to be autonomous learners (CDC, 2015). The curriculum has simply touched upon the term learner autonomy without further illustration and clear specification of the strategies. The teachers are expected to facilitate the students in the process of learning. To meet the objective of the curriculum, National Centre for Education and Development (NCED), Educational Training Centre (ETC) and Nepal English Language Teachers' Association (NELTA) are conducting several trainings and workshops to equip the teachers with modern trends of pedagogy. Lot of discussions and debates take place to replace teacher fronted classroom scenario with leaner engaging strategies. Do our teachers practically use the things they learn in the trainings and workshops?

I have some vivid memories of childhood days. During school days, the sticks in the hand of teachers used to be a frequent scene. The teachers entered the classroom, and started teaching the lesson at their will without paying any attention to the readiness of students for learning. They did not care for motivation of students as they had stout stick in their hands. We had to strictly obey what the teachers said such as saying 'yes' to the way they taught and copying down the things written on the blackboard. We hardly had any chance for questioning or sharing our experience. If anyone asked more questions, it was supposed to be a sign of disobedience. 
Reflecting back to my initial phase of teaching career, I joined a private school in Sarlahi after I completed higher secondary level of education. I had a perception that the students had to obey me at any cost. Otherwise, I would lose value in the class and ultimately my job would be at risk. The whole school environment was influencing my activities in the class. Most of the teachers were found carrying sticks and punishing the students mercilessly.

My experiences and observations set a contradictory scene with regard to autonomy. So, contradiction between what is preached and practiced led me to delve high deep into the issues of learner autonomy

\section{Research question}

The aim of this research was to explore the perceptions and practices of teachers in the context of Nepalese secondary EFL classroom. In order to address this aim, the following research question wereformulated.

How do EFL teachers perceive and practise learner autonomy in secondary Nepali EFL classrooms?

\section{Learner autonomy revisited}

Autonomy is not a linguistic concept, but has been brought into language teaching from the field of psychology, educational theory, and political philosophy as viewed by Benson (2009). "It has been claimed that autonomy is central to lib- eral values such as freedom, rights, democracy, legitimacy, justice and equality"(Elena \& Nucamendi, 2014, p. 17). So, it seems pertinent to have integrated view of learner autonomy.

There has been a significant growth of interest in autonomy in language teaching globally since the turn of $21^{\text {st }}$ century as Benson (2009) mentioned. Now, learner autonomy has been an indispensable part of language teaching and learning.

A proverb derived from Chinese culture 'Give me a fish and I eat for a day. Teach me to fish and I eat for a life time' is associated with learner autonomy. Holec (1981) defines autonomy as "the ability to take charge of one's own learning" (p.13). It is argued that learner autonomous classroom is a place where learners and teachers have constructive interaction with each other and learn from each other. The teacher is responsible for helping learners become aware of alternative strategies and learning styles (Camilleri, 1999). In line with their views, I believe that autonomous learners show active participation and initiation in learning process. Sinclair (2009) outlines that "Learner autonomy is a construct of capacity which is operationalized when willingness is present" (p.185). In a mission of making our learners 'critically aware of language learning' (Miller, 2009, p. 110), there is a need to support our learners to manage their learning and help them to develop language learning strategies as Cotterall (2000). In my experience as a student as well as a teacher, I have realized that there are problems of putting ideas of learner 
autonomy into practice. Thus, willingness seems to be an important factor to promote learner autonomy.

\section{Eastern perspectives}

Education is the process of bringing out the potential that is latent in every human being.

-Swami Vivekananda

Out of multitude of Eastern perspectives, I basically deal with Hindu perspective and Buddhist perspective on learner autonomy.

\section{Hindu perspective}

Ancient Hindu belief is that teachers are source of richness of knowledge, skills and attitude. Teachers are revered as God and enjoy a venerable status. The following chants highlight the significance of Gurus (teachers) in Hindu tradition:

Gurun brahma, guru vishnu; gurudevo Maheshorah;

Gurushakshyat Prambrahma; Tasmaishree guravenamah!

I prostrate to that Sri Guru, who is himself Brahma, Vishnu

and God Maheshvara, and who is verily the Supreme Absolute itself.

I salute such a Guru!

(Vishwa Hindu Parisad, 2004, p.5)

Etymologically, 'Gu' means darkness and ' $R \mathrm{u}^{\prime}$ means remover. We have a belief that Guru is the remover of darkness or ignorance. In this sense, guru is the light of knowledge and inner guiding force that removes our ignorance. The words of gurus are like mantras and the authority of guru cannot be questioned. There is extraordinary relationship between teacher (guru) and student (shisya). Guru Purnima is also celebrated to pay respect to teachers. Regarding learning tradition in Ancient Hindu tradition, Dorga and Gulati (2006) mention that ancient Indian system of education was in the form of 'Gurukula' (the home of the teacher) in which pupils had to stay with the teacher until the completion of education.

Method of teaching in the Gurukul or the Vedic education was teacher-fronted and product oriented guru-shisya system in which pupils were engaged in collective learning through mutual engagement in learning activities as Sharma (2013) mentioned. In Gurukul system of education, only few selected pupils got a chance to receive education. The student teacher relation was individualized and hierarchical. The teachers loved and imparted wisdom to the learners. The gurus always showed right paths to the learners. It is evident that the teachers had an authoritarian role. The students hardly enjoyed the freedom of learning.

With regard to autonomy in the Gurukul system, Sharma (2013) further summaries that teachers (gurus) had full autonomy to design curriculum and organization and management of Gurukulas. The learners were not deprived of freedom at all. They also enjoyed some degree freedom and autonomy of choice in terms of selecting 
teachers or institutions. They had freedom to choose better gurus and institutions for better knowledge. The pupils used to take part in different debates and discussions and expressed their views. The Gurukul system also highlighted the need of self- directed learning.

\section{Buddhist perspective}

It is evident that Buddha himself was an epitome of autonomous learner. He was enlightened through rigorous penance, deep contemplation and sacrifice of pleasures. So, Buddhist philosophy of education is based on self-inquiry and problem solving. The goal of Buddhist education is to attain wisdom and an individual autonomy is given adequate priority with a belief that an individual as a liberation seeking soul has a potential to realize this state of wisdom as Kung (1996) asserts.

The Buddhists monks take control of their self through meditative practices for liberation. Similarly, this practice may be linked to learner autonomy in which the learners take charge of their own learning for better future. In Buddhist philosophy of education, learners are put at the centre and they are given an opportunity to chart their learning journey. In addition, the learners are encouraged for self -discipline, control, hard work and meditation.

\section{Review of previous studies}

Many research studies have been carried out on the issues of learner autonomy. However, the present study has focused on exploring perspectives and practices of EFL teachers on learner autonomy in the context of Nepali EFL classroom.

Willis (2011) in a study conducted at the University of Queensland for investigating whether, or not, students attending English Language Preparatory School at Ba_kent University are ready to be involved in autonomous language learning. He found that before any interventions aiming at fostering autonomy are implemented, it is necessary to explore learners' readiness for autonomous learning in four different areas. These areas are as follows: (a) learners' motivation level in learning English, (b) learners' use of metacognitive strategies in learning English, (c) learners' responsibility perception of their own and their teachers' in learning English and (d) learners' practice of English in the outside class activities.

Similarly, Kocak (2003) carried out a research at Middle East Technical University. He identified that using assessment for learning may develop learner autonomy. However, very often Assessment in Foreign Language is reduced to a set of strategies that did not always achieve the desired outcome. The study addressed an issue regarding the qualities of teacher- student relationship that supported learner autonomy.

Okazaki (2011) in a study concluded that the students could be helped by learner autonomy focused instruction to develop motivation in learning English in a Japanese University EFL setting. Both qualitative and quantitative data from twenty one students in the group with 
learner autonomy support and nineteen students who received the conventional instruction without learner autonomy support were analysed. The focus of the analysis was to determine the trajectory of motivational development in terms of type and students' perceptions of their level of motivation using the self determination theory (SDT). The findings of the study suggested that the students receiving learner autonomy support performed better and were more motivated than students who did not receive the support.

In a study, Joshi (2011) concluded that more than 80 percent learners of Master level were found to be aware of the goals and process of learning English. More than 74 percent of teachers of university experienced that autonomous learners were good learners. The teachers were found as facilitators. Almost all the teachers felt that autonomous learning ensured better proficiency and performance. But this research is positivistic in nature. It does not specifically interpret the contexts of educational system as well as stories of teachers and students.

Neupane (2001) in a study mentioned that learner autonomy worked in any culture provided that the teacher also had autonomy to some extent and curriculum was designed accordingly. The study highlighted that total autonomy was neither feasible nor desirable in formal language learning contexts. But she argued learner autonomy as a necessary condition for making someone lifelong learner. The findings of the study indicated that learner autonomy seemed to be applicable in most of the formal language learning contexts (schools, colleges and universities) of Nepal where the learners learn English. More specifically, the study highlighted the need of learner autonomy in the English language teaching in Nepal in general.

\section{The research gap I noticed}

Based on literature review, I noticed that learner autonomy is crucial to explore the process of teaching and learning for creating autonomous learning environment. However, none of the research studies I came across explored the perceptions of Secondary Level EFL teachers and their strategies as well as teacher-student relationship to promote learner autonomy. Till date in Nepal, I did not come across any research study on learner autonomy using narratives of the EFL teachers. There is dearth of research in this area inspired me to carry out this study.

\section{Interpretivism as paradigmatic stand}

I adopted different lenses (Saldana, 2015) to view the world qualitatively and my research agenda demanded interpretive paradigm as it consolidates researchers' local understanding of the life-world experiences of teachers and students and of the cultures of classrooms, schools as well as the communities they serve (Taylor \& Medina, 2001). The interpretive paradigm holds a belief that reality is socially constructed; that is, there is no single observable reality (Rowlands, 2005). The paradigm of interpretivism helped me, as a 
researcher, to understand and construct a new meaning on learner autonomy interpreting the practices and experiences of the English teachers. Such new learning can be drawn by interpreting and reflecting on English teachers' experiences and narratives.

\section{Methodological considerations}

This research is based on the interpretation of stories, values, beliefs and experiences of the research participants who are the English teachers.

\section{Ethnography}

I employed ethnographic elements in research as a supporting method of interpretive paradigm that usually incorporates the researcher participating and watching people's day to day activities for an extended period of time, asking questions through informal and formal interviews and collecting documents and artifacts as Hammersley and Atkinson (2007) asserted. Ethnography is a written account of the cultural life of a social group, organization or community which may focus on a particular aspect of life in that setting (Watson, 2008a). In essence, I employed ethnographic perspective as my engagement method in the field due to ethnographic nature of my research.

\section{Narrative genre}

Following Barkhuizen, Benson and Chik (2014), "Narrative inquiry brings story telling and research together either by using stories as research data or by using story telling as a tool for data analysis or presentation of findings" (p. 13). In this connection, I employed narrative analysis that supported me to incorporate ethnographic tales of the participants. Stories, vignettes and experiences were the treasures which helped to generate knowledge and insights. I mentioned the vignettes of the participants in different chapters to set the scene and provided backdrop for my research. I have presented the tales/ lived experiences of the participants.

\section{Selection of research site and participants}

I selected community schools as the site, and English teachers who have been teaching English in secondary level as the research participants purposively for my research. I talked to some English teachers and explained briefly about my research. I made them clear that the participants must give time for observation and interview for generating data. I have chosen two secondary level English teachers as the focus from two community schools of Lalitpur district. They are experienced permanent teachers of community schools. They showed their willingness to support me for the research. My intention was to uncover the perspectives and practices of teachers on learner autonomy from the ELT teachers of public school who have been teaching more than a decade. And at the same time, I could get a chance to enrich my data about the existing practices on learner autonomy through the head teachers and the resource persons, other teachers as well as students of the sampled schools. 


\section{My field engagement strategies}

Observation, interview and field notes, and group discussion were my field engagement strategies.

\section{Observation}

I used observation as a tool to generate data for my research. Observation offered me an opportunity to gather data (Cohen et al. 2007) from naturally occurring social situations. I used notebook and observation form for observation followed with taking photographs with consent from the participants. I observed activities and interactions taking place in the classroom context around fifteen times. Through personal observation, I was able to figure out whether the participants really practiced learner autonomy in their EFL classrooms.

\section{Interview}

I interviewed EFL teachers to understand the setting at various points in the study which provided me a chance to learn how people reflected on their behaviour, events and other things. Interview was particularly instrumental to get in depth view of teachers' perspectives and practices with regard to learner autonomy in an EFL classroom.

\section{Group discussion}

I conducted series of group discussions with students, teachers and head teachers to yield credible information. The group discussions encouraged them to feel free to share their ideas and opinions. It was fruitful as I collected relevant information through sharing and discussion of the participants involved in the group discussion. Most importantly, I perceived contradictions in perceptions and practices of the teachers.

\section{Field notes}

I noted down different pieces of information and events that took place during my research journey. I made notes of nonverbal means of communication such as gesture, posture and facial expressions which supported me for the interpretations of the texts and meaning making process.

\section{Data collection and meaning constructing process}

The data generation process commenced from October, 2016 to January, 2017 AD. First of all, as per ethical consideration, I took consent from the participants to meet them in the school, observed their class and took an interview. I interviewed the participants seeking permission at their convenient time in the schools. Sometimes I informally had conversation with my participants over the phone for the accuracy of data. Each interview was duly recorded. I maintained field notes based on observation and interaction which supported me to generate themes. I formally interviewed the participants and stakeholders until I had sufficient data for interpretation and meaning making process. Talking to stakeholders was an amazing moment to collect more information. 
The research participants were very enthusiastic and agile. They were ready to provide as much information as possible. After building rapport with the participants, it was easier for me to collect information on the dimensions of learner autonomy and their actual practices in the classroom. I assured my participants about confidentiality of information. I remained tremendously polite and tried my best to maintain due respect to my participants. So, I could grab the flow of information through the interview. I never gave them any kind of pressure. I took interview at their convenient time having sought their consent. I went to their schools about ten times to observe their classes, took their interview and interacted with them.

\section{Data analysis procedure}

As a qualitative researcher, the process of data analysis of the research inquiry incorporated making sense out of texts and collected data which involved consolidating, reducing and interpreting for the process of meaning making as Merriam (2009) outlined. After the collection of data, I was in a huge dilemma of what to do further. Then, gradually I organized the data keeping the research questions of my research in due consideration. Transcribing the recordings was a daunting task. I read all transcriptions thoroughly to make sense of the information collected. I maintained coherence of the field notes.

I developed core themes and sub themes linking them with relevant theories and literature. I interpreted and analysed the data through interpretive lens.

\section{Major insights}

Don't let the noise of other's opinions
drown out your own inner voice

-Steve Jobs

I have drawn the following insights on the basis of my research questions and prolonged engagement in the field schools having based on analysis and interpretation of the data derived through observation and interview. I divided the major insights under three headings: teachers' perceptions on learner autonomy, teachers' strategies for fostering learner autonomy as well as challenges for fostering leaner autonomy.

\section{Insights based on teachers' perceptions}

The study explores that teachers need to be a role model for the students. They need to maintain a close connection with the learners. Regarding school environment, it has to be homely and autonomy-supportive. The research participants opined that students do not learn in the controlled environment. They disagreed to maintain pin-drop silence in the classroom even if they did so in the initial phase of their teaching career. The participants focused on helping learners to explore new ideas. They agreed to the point that unnecessary intervention from the teachers hampers their creativity.

Most importantly, teachers need to be friendly, caring and agreeable. They have a huge role to play in the society. Further, 
they contended that the learners need to be encouraged to take charge of their learning highlighting their strengths. They agreed that that motivation is a prerequisite to learner autonomy. According to them, English language has played an important role to foster/ prevent learner autonomy. Those students who are good at English were found extrovert in the class. They took the lead roles. Those who were not able to speak English showed hesitation to take part in discussion and interaction.

\section{Insights based on teachers' strategies}

The study examines the strategies of teachers to promote learner autonomy. The research participants involved the learners in conversation as far as possible. They gave top priority to incorporate the ideas for better learner engagement. They engaged students in group work, pair work, debates and brainstorming to generate their ideas. But, it was very hard for them to manage the class due to many students. The participants highlighted the importance of thinking contextually as a way of fostering autonomy.

The research participants stressed the importance of interaction as a good technique to foster learner autonomy. There is a shift from TTT (teacher talking time) to STT (student talking time). They were found eager to engage the students in productive interaction as it would help to generate new ideas and ensure greater participation of students, but due to large class size, it was quite hard for them to engage students in interaction.

\section{Insights on teachers' challenges}

The study unfolds the challenges faced by teachers while fostering learner autonomy. The participants thought that lack of clear concept of learner autonomy created problem to foster it in the classroom. The research thought that western concept of learner autonomy could be adapted keeping in mind eastern societal values and beliefs embedded in teaching and learning. Lack of teaching materials created problems to engage students in creative tasks.

Moreover, there are several challenges such as apathy of administration, reluctance of teachers, inadequate resources, etc. to promote learner autonomy

\section{Conclusion}

The insights derived on the basis of teachers' perceptions and practices on learner autonomy helped me to draw the following conclusions.

It appears that teachers have some practical problems. As the teachers attempt to promote learner autonomy, they are caught in confusions and dilemmas due to general opinions of the people and established socio-cultural norms and habitus. So, this emerging dilemma/tension of the teachers poses a difficult situation of to be or not be. The EFL teachers perceive learner autonomy as simply giving freedom to learners. From the experiences and sharing of participants, it is obvious that students need constant care and attention from teachers. The teachers are assumed 
to be a guide by the side of students. Therefore, teachers need to create a favourable environment for fostering learner autonomy. The research participants contend that large class seems to be an impediment to promote autonomy. Well-managed classroom and autonomy supportive environment may support to foster learner autonomy.

It is evident from the experiences of the participants that motivated learners perform better. Positive motivation may be instrumental to kindle the interest of the students in learning. It is always a fascinating idea to motivate students for learning without any kind of punishment. Positive parenting and positive discipline seem to be wonderful techniques to create autonomous learning environment.

Attempting to promote learner autonomy as per western perspective may be a flaw on the part of teachers and stakeholders. The way the teachers conceptualize and practice learner autonomy seems to be influenced by the socio-cultural realities. Diverse sociocultural and geopolitical dimensions may play an important role to promote learner autonomy. Therefore, I attempted to explore embedded norms and habitus for learner autonomy through Hindu and Buddhist perspectives. We need to be mindful about the translated and imported version of learner autonomy that may not fit with the expectations of our learners. We need to prefer pragmatic view of learner autonomy relating it to autonomous learning with incorporation of technology and innovation. It is claimed that teacher and technology are inseparable part of teaching and learning process.

The participants are disappointed with the practice of punishment, which remains to be a critical factor. The prevailing tales of punishment for the betterment of learners seem to have been embedded in the psyche of the teachers. Therefore, learners cannot exercise their freedom when teachers take support of stick to control their class. With an expression of doubt, the research participants claim that learner autonomy still seems to be a wild goose chase in our context when the stakeholders are not supportive, caring and sensitive towards the needs of the learners. It seems pertinent to maintain psychology of self- esteem and level of motivation of the learners to promote learner autonomy. Furthermore, with regard to fostering learner autonomy, the options could be "think globally and act locally" incorporating the fundamental dimensions of learner autonomy. Therefore, it seems pertinent to have paradigm shift with regard to learner autonomy and freedom in the context of Nepal. Nevertheless, it is quite tougher than said as the teachers face'a situation of to be or not to be' due to contradictions between educational policy and embedded social cultural practices and expectations.

\section{Pedagogical implications}

Insights drawn from my research endeavour helps curriculum developers give due consideration to include the contents in the curriculum having negotiation with teachers and learners to 
engage learners in autonomous learning process.

This research endeavour creates teachers' awareness about classroom dynamics such as effective group work, pair work and interactive use of target language to promote learner autonomy. Regarding significance of learner engagement in productive learning, Louis (2003) argues that when students become more involved in their own learning, taking an active part in making decisions, they might feel a sense of ownership and commitment to the process, and learning might be more meaningful, resulting in better class performance (p. 1). The stakeholders are also expected to recognize the role of learners as creative beings and support them for independent learning by creative interactive learning environment at school.

This study also draws the attention of stakeholders to explore the dimensions of learner autonomy. It is not a good idea to use imported or translated concept of learner autonomy. So, it seems pertinent to adapt facets of learner autonomy that fit our context.

\section{References}

Bakhtin, M. M. (1981). The Dialogic Imagination. Texas: University of Texas Press

Barkhuizen, G., Benson, P. \&Chik, A. (2014). Narrative inquiry in language teaching and learning research. New York, NY:Routledge.

Barfield, T. (2009). Maintaining control: Autonomy and language learning.Hong Kong: Hong Kong University Press.
Benson, P. (2009). Making sense of autonomy in language learning. In R. Pemberton et al. (Eds.), Maintaining control: Autonomy and language learning. Hong Kong: Hong Kong University Press.

CDC (2015). Secondary Education Curriculum. Bhaktpur: Author

Cohen, L., Manion, L., \& Morison, K. (2000). Research methods in education ( $7^{\text {th }}$ ed.). London: Routledge.

Cotterall, S. ( 2000). Promoting learner autonomy through the curriculum: Principle for designing courses.ELT Journal 54, 2.

Dam, L. (1995). Learner autonomy 3: From theory to classroom practice. Dublin: Authentik.

Dorga, S. \&Gulati, S. (2006). Learning traditions and teachers' role: The Indian perspective. Educational Research and Reviews, 1(6), 165-169.

Elena, M., \&Nucamendi, L. (2014).Autonomy in language learning. Mexico: Universidad de Quintana Roo.

Hammersely, M. \& Atkinson, P. (2007). Ethnography. New York, NY: Routledge.

Holec, H. (1981). Autonomy in foreign language learning. Oxford: Oxford University Press.

Joshi, K. R. (2011). Learner perceptions and teacher beliefs about learner autonomy in language learning.NELTA Journal, 16(1-2), 13-29.

Kocak, A. (2003). A study on learners' readiness for autonomous learning of English as a foreign language. An MSC Thesis Submitted to Middle East Technical University, Turkey.

La Ganza, W. T. (2008). Learner autonomy: Interrelating and the will to empower. In T. Lamb, \&H. Reinders, (Eds.), Learner and teacher autonomy (pp. 63- 
82).The Netherlands: John Benjamins Publishing Co.

Little, D. (1999). Learner autonomy is more than a western cultural construct. In S. Cotterall\& D. Crabbe (Eds.), Learner autonomy in language learning: Defining the field and effecting change. New York, NY: Peter Lang.

Little, D. (2007). Language learner autonomy: Some fundamental considerations revisited. Innovation in language learning and teaching, 1(1), 1430

Little, D. (2009). Learner autonomy, the European portfolio and teacher development. In R. Pemberton et al. (Eds.), Maintaining control: Autonomy and language learning. Hong Kong: Hong Kong University Press.

Louis. S. R. (2005). Helping students become autonomous learners: Can technology help? Retrieved on November 19, 2005 from http://home.learning times?go=1042165

Miller, L. (2009). Reflective lesson planning: Promoting learner autonomy in the classroom. In R. Pemberton (Eds.), Maintaining control: Autonomy and language learning. Hong Kong: Hong Kong University Press.

Neupane, M. (2010). Learner autonomy: Concepts and considerations: Journal of NELTA, 15(1-2): 114- 120.

Nucamendi, M. E. (2014). Autonomy in language teaching: the learner, the teacher and the institution. Mexico: Universidad de Quintana Roo.

Okazaki, M. (2011). An Investigation into the Relationship between Learner Autonomy Support and Student Motivation in the Japanese University Setting. A PhD thesis submitted to the University of Birmingham.
Rowlands, B. (2005). Grounded in practice: Using interpretive research to build theory. The electronic journal of business research methodology, 3(1), 81-92.

Saldana, J. (2011b). Fundamentals of qualitative research. New York, NY: Oxford University Press.

Saldana, J. (2015). Thinking Qualitatively: Methods of mind. Thousand Oaks, CA: Sage Publications.

Sharma, B. K. (2013). Hinduism and TESOL: Learning, teaching - student teacher relationships revisited. Language and Linguistics Compass, 7(2): 79-90.

Sinclair, B. (2009). The teacher as learner: developing autonomy in an interactive learning environment. In R. Pemberton (Eds.), Maintaining control: Autonomy and language learning. Hong Kong: Hong Kong University Press.

Willis, J. E. (2011). Towards learner autonomy: An assessment for learning approach An Unpublished PhD Thesis Submitted to Queensland University of Technology, Australia.

Willis, J.W. (2007). Foundations of qualitative research. Thousand Oaks, CA: Sage.

Contributor: Chet Nath Panta is an MPhil graduate in English Language Education at Kathmandu University, Nepal. He is currently working there as a visiting faculty. He is also the head teacher of Sisneri Secondary School, Lalitpur. His areas of interest include learner autonomy, critical pedagogy and issues related to transformative leadership. 